\title{
PRACTICAL ASPECTS OF SOCIAL DISCOUNT RATE DETERMINATION IN UKRAINE
}

\author{
Vitaliy Kuzmenko ${ }^{1}$ \\ Svitlana Urvantseva ${ }^{2}$
}

DOI: https://doi.org/10.30525/978-9934-588-15-0-35

Abstract. The essence of the social discount rate (SDR) and four methodological approaches to its determination are considered in the current article. The international practice of SDR calculation is analyzed. The authorial methodology of SDR calculation is proposed and its validity within calculation in Ukraine is proven. The main goal of the current study is to summarize different approaches to social discount rate determination and to analyze challenge within its calculation. The present study is also designed to develop a methodology for SDR calculation in Ukraine. Methodology. The general scientific methods are applied within the research process, namely: the historical method is used in the context of scientific approaches to SDR definition genesis; the basic methods for SDR calculation rely on systematic approach and abstraction; the logical generalization method serves to study the worldwide experience of SDR use; mathematical analysis and modeling are used to develop The authorial methodology of SDR calculation. Research findings. The social discount rate is determined in this paper as a parameter that reflects the quantitative side of the budgetary and social impact of public investment. The four main approaches that are predominantly applied in the market economy to determine SDR have been identified and disclosed, namely: social rate of time preferences (SRTP) approach, social opportunity cost of capital (SOC) approach, the consumer equivalence approach $\left(\mathrm{SDR}_{\mathrm{CEM}}\right)$, and the approach based on the concept of shadow price of capital (SPC). In accordance with summarized in the current research table, which reflects the calculation method and the SDR value worldwide, the SRTP approach is more commonly used in developed

\footnotetext{
${ }^{1} \mathrm{PhD}$ student of Corporate Finance and Controlling Department,

SHEE «Kyiv National Economic University named after Vadym Hetman», Ukraine

${ }^{2}$ Phd in Economics,

Associate Professor of Corporate Finance and Controlling Department,

SHEE «Kyiv National Economic University named after Vadym Hetman», Ukraine
}

(C) Vitaliy Kuzmenko, Svitlana Urvantseva 
countries than in developing ones and the SOC method is more popular in developing countries than in developed ones. In practice, the SPC approach is difficult to implement, because it requires the calculation of the shadow capital cost according to the lifespan for each individual project. The practical value of the study. According to the results of the current study, the authors propose a method for SDR calculation in developing countries. The model is based on the «social rate of time preferences» approach and takes into account the following aspects: 1) life risk level fluctuations and the elasticity of marginal social utility of consumption; 2) differentiation of monthly consumer spending per capita (in UAH) in crisis periods and periods of economic growth; 3) supplementing the risk to life indicator with the average rate of such risk increase; 4) the methodology for determining the net rate of time preferences. The representativeness of the authorial methodology based on SDR calculation and its value in accordance with Ramsey methodology, modified approach of Sheluntsova and Boardman approach comparison is substantiated.

\section{Introduction}

The search for Ukrainian exit out of the geopolitical and socio-economic crisis calls for the application of new requirements for public policy, especially in the case of state financing of the entrepreneurial investment activity.

The social discount rate, which either expresses alternative opportunities for society to use resources between a couples of timeframes or between different investment options, represents a parameter that reflects the quantitative side of the budgetary and social impact of public investment. At the same time, the social discount rate is equal to the time preferences of consumption and alternative return on capital in case of a perfect capital market presence that is not typically for the Ukrainian economy. Although some scientists have suggested that the social rate is equivalent to the market interest rate within the market economy [1].

Thereby, the issue of the social rate determination is becoming rather important currently. The relevance of such research is caused due to the following facts: firstly, due to the availability of different scientific points of view on the application of methods for the social discount rate determination (hereinafter - SDR) in developed countries; secondly, the need for SDR determination in developing countries; thirdly, the lack 
of methodological approaches for SDR definition at the national level in Ukraine.

The problem of SDR definition has its widespread only in the 1930th among scholars and practitioners in the field of public finance [2]. Thus, considering the historical background of the above-mentioned question, it can be noted that the primary works (W. Baumol [3], S. Marglin [4]) concerned the study of the particular components of the rate structure. A bit later, some further works have been appeared, where the authors suggested the use of a confidence interval for SDR calculation, using several different estimation approaches (S. Azar [5], M. Percoco [6], H. Lopez [7]). However, over time, the scientists [8; 9; 10; $11 ; 12 ; 13 ; 14 ; 15 ; 16]$ began to analyze the problems of choosing the appropriate method of SDR calculation and to provide criticizing the suitability of approaches to its determination worldwide. Nevertheless, a number of scientists $[1 ; 17 ; 18]$ mentioned the current parameter as the most important among those that determine the socio-economic value of investment projects.

There is only a limited number of scientific researches on this question in Ukraine [19], which do not provide a critical analysis of the SDR approaches and the importance of its application in evaluating investment projects to be supported by state.

Thus, the main goal of the current study is to summarize different approaches to social discount rate determination and to analyze challenge within its calculation. The present study is also designed to develop a methodology for SDR calculation in Ukraine.

\section{Genesis of scientific approaches to the social discount rate calculation}

The social discount rate is used within a rather wide area. In accordance with the practice worldwide, the rate is applied for consideration of all types of projects related to the public sector of economy. Generally, there are several theoretical approaches to the SDR evaluation.

The capital investments efficiency limit [20] in the form of one-off expenses, efficiency rate (e) is used within the command-type economic system as the SDR [21, p. 15]:

$$
\sum_{t=t_{H}}^{t_{K}}\left(P_{t}-B_{t}-K_{t}\right) \cdot(1+e)^{t_{p}-t}=0,
$$


where $P_{t}$ - sales revenue during the timeframe of year $t ; B_{t}-$ current costs during the timeframe of year $t$, excluding any renovation charges; $K_{t}-$ one-off expenses of production during the timeframe of year $t$.

The following four approaches are mainly used to define SDR within the market economy, namely:

1) SRTP approach, that is based on the concept of social rate of time preferences (SRTP), characterizing the compensation to be provided for rejection of the current consumption alternative in favor of the future generations welfare.

The social rate of time preferences is traditionally calculated in accordance with Ramsey formula, which can be deduced by solving the problem of maximizing public consumption benefit [2]:

- for the discrete case: $\sum_{t=0}^{T} \frac{U\left(C_{t}\right)}{(1+\rho)^{t}} \rightarrow \max$

- for continuous case: $\int_{t=0}^{T} U^{\prime}\left(C_{t}\right) \cdot e^{-\rho t} d t \rightarrow \max$

where $\rho$-individual rate of time preferences, $U\left(C_{t}\right)$ - the utility derived from consumption.

In case of the following type of utility function:

$$
U\left(C_{t}\right)=\frac{1}{1-\mu} \cdot C_{t}^{1-\mu},
$$

where $\mathrm{U}(\mathrm{Ct})$ - the utility derived from consumption, $\mu$ - elasticity of marginal utility, we will get the following function:

$$
\begin{aligned}
\frac{\frac{d}{d t}\left(\frac{d\left(U\left(C_{t}\right) \cdot e^{-\rho t}\right)}{d C_{t}}\right)}{\frac{d\left(U\left(C_{t}\right) \cdot e^{-\rho t}\right)}{d C_{t}}} & =\frac{\frac{d}{d t}\left(C_{t}^{-\mu}-e^{-\rho t}\right)}{C_{t}^{-\mu}-e^{-\rho t}}=-\frac{-\rho e^{-\rho t} C_{t}^{-\mu}-\frac{\mu}{C_{t}} e^{-\rho t} C_{t}^{-\mu} \frac{d C_{t}}{d t}}{C_{t}^{-\mu} \cdot e^{-\rho t}}= \\
& =\rho+\mu \cdot \frac{d C_{t}}{d t} \cdot \frac{1}{C_{t}} \rightarrow S R T P=\rho+\mu \cdot g,
\end{aligned}
$$

where $\rho$ - individual rate of time preferences; $g$ - per capita consumption growth rate, which depends on revenue growth forecast. This component is often determined by estimating GDP growth rates. It ranges from $1.0 \%$ to $4.6 \%$ in accordance with international practice; $\mu$ is the elasticity of marginal utility of consumption that is unrepresentative in accordance with scientific opinion [22]. 
However, the scientists take into account the above-mentioned component within SDR assessment methods. They determined $\mu$ by one of three methods: direct poll, indirect behavioral evidence and the identification of social value. N. Stern introduced the algorithm of $\mu$ mathematical determination [23]. The scientist assumed that income of the population increases over time and created a utility function expressed by the following formula:

$$
\mu=\left(1-\frac{\delta}{r}\right) \cdot \frac{Y}{S}, \Rightarrow \mu=\frac{r-\delta}{\beta \cdot(r-\gamma)+\gamma},
$$

where $\mu$ - elasticity of marginal public utility of consumption (the parameter $\mu$ ranges from $1,0 \%$ to $2,0 \%$ in accordance with international practice); $r$ - the alternative cost of capital; $S$ - population maintenance; $Y$ - population income; $\beta$ - the average savings rate; $\gamma$ - rate of income (wages) increase; $\delta$-net time preferences rate without the algorithm for its determination. It generally ranges by experts in the range of $0 \%-0,5 \%$ [1].

Although many scientists tend to exclude it from the calculation or take it for zero, justifying this with the thesis that the future generations well-being cannot have a downward trend (be worse than it is now) $[14 ; 18]$. However, in light of established tendency to public debt volume increase in Ukraine (Figure. 1 and Figure. 2), it is possible to prove the opposite fact. Thus, in accordance with authorial calculations for our country $\delta=0,44 \%$ (it is defined with the use of method of least squares, GDP growth function depending on the public debt per person growth).

Due to the fact that the alternative cost of capital reflects the maximum return on alternative investments, the last one will be equal to the weighted average interest rate on the banking retail deposits in UAH for the respective year within our calculations (without on demand deposits), because this rate reflects the alternative possibilities for free cash placement in Ukraine. The average rate of savings can be calculated as the ratio of the cumulative part of the income of the population to the total income.

There is also an alternative (D. Pearce) approach to calculate the social rate of time preferences [25]. The scientist proposed to modify the formula (3) adding it to another parameter that reflects the change in life risk. In other words, he divided $\rho$ into two parts, namely: $\delta$ is the «net» rate of time preferences and $L$ is the life risk level:

$$
S R T P=\sigma+L+\mu \cdot g,
$$




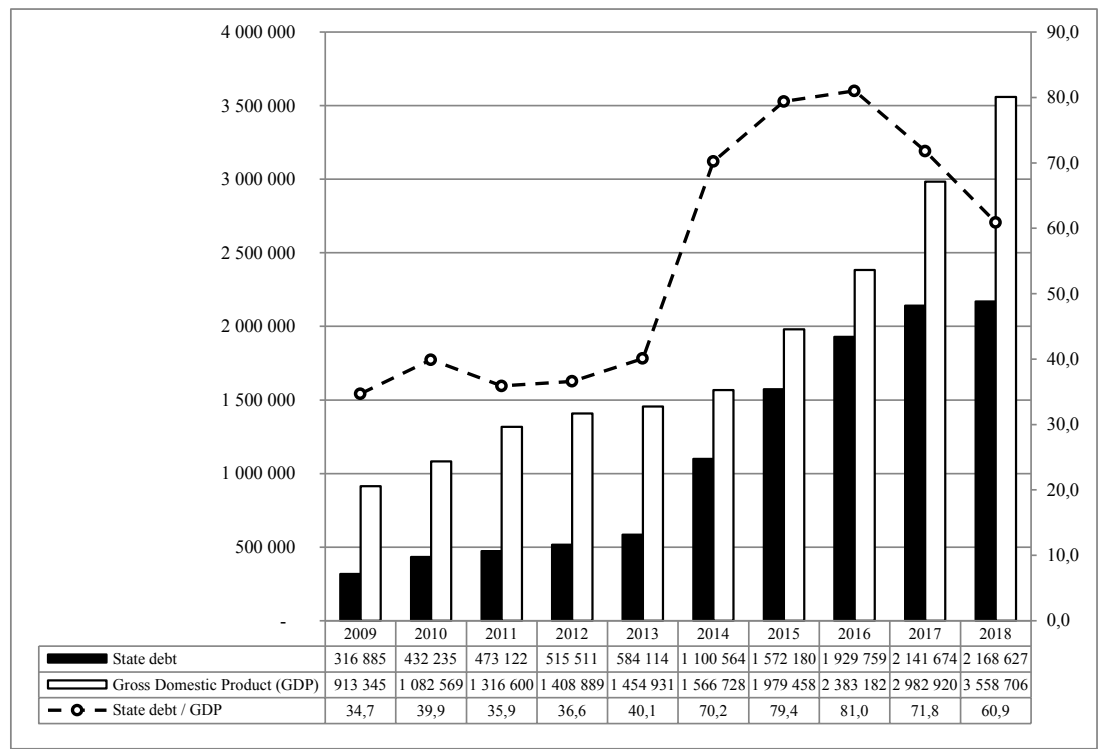

Figure 1. Dynamics of total public debt and GDP in Ukraine during 2009-2018 years (mln. UAH, \%)

Source: developed by authors based on [24]

where $\sigma=\delta$ - net rate of time preferences, $L=\rho$ - the life risk level that is defined as the proportion of deaths to the total population [26]. In accordance with conducted researches, this value is changing from $0,05 \%$ to $3,0 \%[12 ; 14]$.

Simultaneously, according to the methodological approach of M. Sheluntsova, the Ramsey formula is modified by adopting the hypothesis of the need to maximize public utility in case of limited consumption for a certain timeframe. In case of using the Lagrange function to solve the utility maximization problem and the consequences of the series unity theorem and the Taylor series definition, formula (3) has the following form [13, p. 714]:

$$
\operatorname{STPR}=(1+g)^{\mu} \cdot(1+\rho)-1 .
$$

There is a need to emphasize that the social discount rate may have not only positive, but also negative value. The negative SDR value should be interpreted as follows: the significance of the magnitude of social effect for society is minimal with prevailing commercial effect. 


\section{Chapter «Economic sciences»}

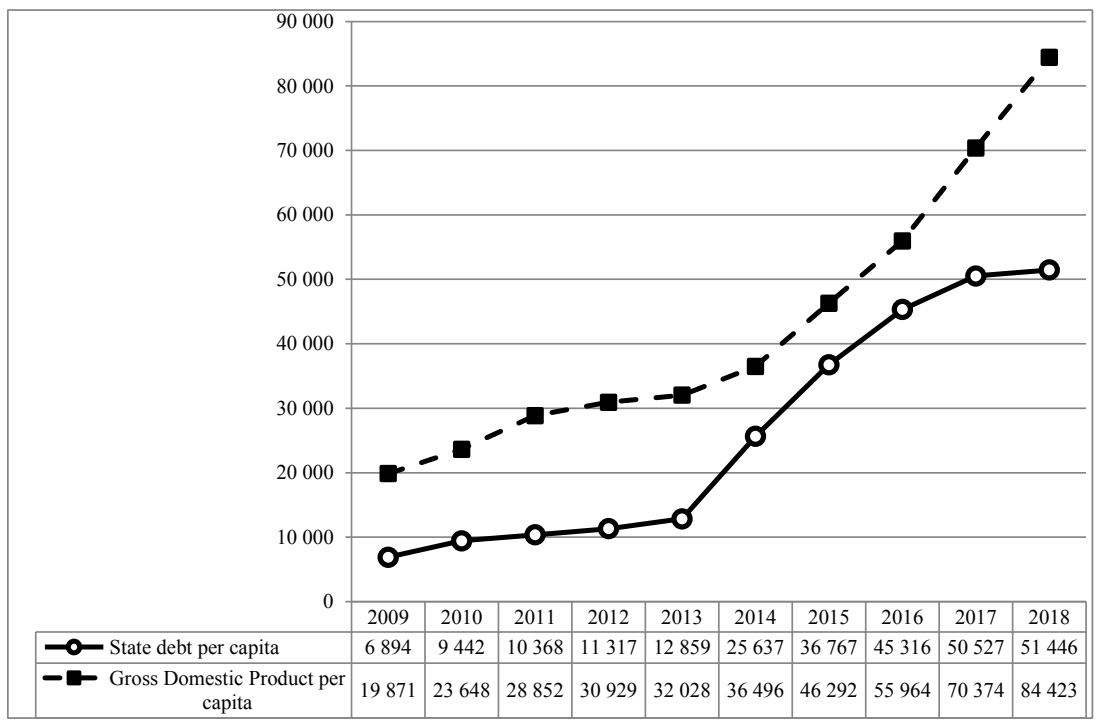

Figure 2. Dynamics of total public debt and GDP per capita during 2009-2018 years (UAH)

Source: developed by authors based on [24]

However, there is the following problem: how to discount cash flow in case of negative discount rate. It seems logical to use alternative rates, but this will lead to a loss of economic sense and results misinterpretation. It is rather important to understand the social effect concept meaning to evaluate the current situation properly. The social effect means a positive consequence for a social group because of investment project implementation. The social effect is expressed in improving the life quality while increasing the service volume or offering new services, increasing their availability, achievability, regularity of their provision, etc. The lack of discounting cash flows, that generate a social effect, actually reflects the minimum requirements of society for the magnitude of the social effect. In this case, the social effect is a qualitative indicator unlike the commercial and budgetary effect, which tends to be expressed quantitatively.

Taking into consideration the above-mentioned facts, the conclusion is that the cash flows, generating the social effect value, are not discounted in 
case of SRTP parameter negative value. Conversely, the high level of social discount rate indicates that there is an opportunity to use public savings to invest into social programs (projects).

2) Social opportunity cost of capital (SOC) approach, based on alternative use of resources in an economy outside the project or social alternative cost of capital. SOC is the highest return on an alternative project with the same level of risk that could be implemented within the private sector or so-called marginal rate of return on risk-free private investment [1].

The basic postulate, underlying the current approach, means the idea that public investment should bring at least the same return as private, since no one has abolished the law of resource scarcity. There is a confrontation / displacement of public and private investment

A. Boardman, D. Greenberg and others represented the algorithm of SOC calculation in their work [27]. Such algorithm includes:

- risk-free interest rate $\left(r_{f}\right)$;

- income tax (tax);

- the nominal tax rate, which is determined in the following way:

$$
r_{n}=\frac{r_{f}}{(1-\operatorname{tax})} \text {. }
$$

- average annual inflation rate $\left(T_{i}\right)$.

Finally, the social alternative cost of capital is calculated in the following way:

$$
S O C=\frac{r_{n}-T_{i}}{1+T_{i}}
$$

If the capital necessary for public investment or private equity projects with public resources financing partially or fully satisfies consumers, the income essential for consumers is usually less than the marginal rate of return on private investment. As a result, the SRD should be lower than SOC.

3) The third approach is based on shadow price of capital (SPC) concept, which allows us to define the efficiency of capital use in the public sector. These benefits are worth more to society than in case of immediate consumption in accordance with the generated flows of future consumption approach. Thus, the total cost of public investment financing is the amount of current consumption that is directly displaced and those future consumption flows that are lost through the shift in private investment [1]. Economic science is aware of two alternative formulas for SPC calculation [28; 29]. 
The first formula is applied, when the rate of savings is expressed in gross profitability (9), and the second one is used, when the rate of savings is expressed as a return excluding depreciation (10).

$$
S P C=\frac{r-s \cdot r}{S R T P+d-s \cdot r},
$$

where $r$ - the gross rate of return on private investment before depreciation, $d$-depreciation rate, $s$ - the rate of saving on gross returns.

$$
S P C=\frac{\lambda-\sigma \cdot \lambda}{S R T P-\sigma \cdot \lambda},
$$

where $\lambda$ - rate of return on private investment excluding depreciation, $\sigma-$ the rate of savings from net profitability.

Although the above-mentioned approach seems to be attractive at first glance, it is difficult to be implemented in practice, as it requires the calculation of the shadow capital cost in relation to the each individual project longevity.

4) The fourth approach is based on the consumer equivalent

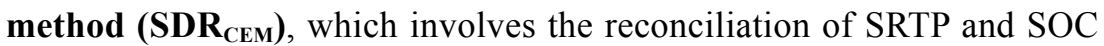
estimation $[1 ; 30]$.

The empirical aspects of social rate of time preferences cause the emergence of this approach and social opportunity cost of capital use. Thus, the SDR values, obtained by calculating SRTP and SOC, are equal to each other in case of perfect capital market condition.

However, the current situation is rather an exception than a rule in practice. In addition, the SRTP indicator does not take into account the implications of government projects for the volume of private investment financing. Moreover, it is assumed that public investment does not replace only private investment, but also private consumption or international borrowing in case of SOC calculation.

In accordance with the consumer equivalent method, the social discount rate is calculated in the following way [31]:

- for closed type of economy:

$$
S D R_{C E M}=\alpha \cdot S O C+(1-\alpha) \cdot S R T P,
$$

- for open type of economy:

$$
S D R_{C E M}=\alpha \cdot S O C+(1-\alpha-\beta) \cdot i_{f}+\beta \cdot S R T P,
$$


where $S D R_{C E M}$ is social discount rate; $\alpha$ is the proportion of funds for public investment, obtained at the expense of private investment; $\beta$ is the proportion of funds obtained at the expense of current consumption; $1-\alpha-\beta$ is the proportion of funds from foreign borrowing; $i_{f}$ is the rate of real return on savings exclusive.

The main among others advantage of current approach is that it does not require an assessment of the alternative cost of capital.

Thus, in case of intermediate conclusions provision, it is possible to define that the definition of the above-mentioned parameters is a rather complicated and often impossible process. However, there are special methods of such calculations in most Western European countries and the USA, but there are no such methods in Ukraine.

\section{International experience of SDR calculation}

The European Commission prepared the first version of the Benefits and Costs Analysis of Investment Projects Manual, outlining the recommended level of SDR, in 1990. The current version of above-mentioned document specifies SDR as 5\%.

In accordance with the World Bank experts point of view, the social discount rate for EU countries is in the range from $2 \%$ to $4 \%$. Other scientists consider the SDR in European countries and USA at the level from $2.5 \%$ to $6 \%$ [6].

The summary table, reflecting the approach to SDR calculation and its value worldwide, is considered base on analysis of M. Sheluntsova [32], Salvador Cruz Rambaud, María José Muñoz Torrecillas [33], Massimo Florio and Emanuela Sirtori [34], Juzhong Zhuang, Zhihong Liang, Tun Lin, and Franklin De Guzman [1] researches (Table 1).

It is established that the SRTP approach is more commonly used in developed countries. At the same time, the SOC method is rather popular in developing ones. There is also a wide range of SDR values worldwide that is related to economic, social, geographical and demographic factors.

\section{Theoretical, methodological and practical aspects of SDR definition in Ukraine}

Despite significant foreign experience, the SDR is not calculated in case of investment projects implementation in Ukraine. SDR use is regulated on the basis of particular explanations of the Ministry of Economic 
SDR in different countries worldwide

\begin{tabular}{|c|c|c|c|c|}
\hline Country & Year & Author & $\begin{array}{c}\text { Calculation } \\
\text { approach }\end{array}$ & $\begin{array}{c}\text { Value, } \\
\%\end{array}$ \\
\hline Germany & 2004 & $\begin{array}{l}\text { Evans D. J. and Sezer H. Social } \\
\text { discount rates for six major countries. } \\
\text { Applied Economics Letters, 11, } \\
\text { 2004. - Pp. 557-560. }\end{array}$ & SRTP & 4,1 \\
\hline \multirow{2}{*}{$\begin{array}{c}\text { Denmark, } \\
\text { Sweden }\end{array}$} & \multirow{7}{*}{2005} & \multirow{7}{*}{$\begin{array}{l}\text { Evans D., Sezer H. Social discount } \\
\text { rates for member countries of the } \\
\text { European Union. Journal of Economic } \\
\text { Studies, Vol. 32, No.1, 2005, } \\
\text { Pp. 47-59. } \\
\text { Evans D. J. and Sezer H. Social } \\
\text { discount rates for six major countries. } \\
\text { Applied Economics Letters, 11, } \\
\text { 2004. - Pp. 557-560. }\end{array}$} & SRTP & 4,5 \\
\hline & & & SRTP & $2,3-2,4$ \\
\hline $\begin{array}{l}\text { The Czech } \\
\text { Republic, } \\
\text { Hungary }\end{array}$ & & & SRTP & $3,1-3,2$ \\
\hline Netherlands & & & SRTP & 3,6 \\
\hline $\begin{array}{l}\text { Belgium. } \\
\text { Finland, } \\
\text { Spain } \\
\end{array}$ & & & SRTP & $4,4-4,7$ \\
\hline $\begin{array}{c}\text { Austria, } \\
\text { Portugal, } \\
\text { Luxembourg, } \\
\text { Ireland, Greece }\end{array}$ & & & SRTP & $5,3-5,6$ \\
\hline Poland & & & SRTP & 6,1 \\
\hline \multirow{5}{*}{ USA } & 2003 & Government Accounting Office & $\mathrm{SOC}$ & 3,0 \\
\hline & 2004 & $\begin{array}{l}\text { Evans D. J. and Sezer H. Social } \\
\text { discount rates for six major countries. } \\
\text { Applied Economics Letters, 11, } \\
\text { 2004. - Pp. 557-560. }\end{array}$ & SRTP & 4,6 \\
\hline & 2007 & $\begin{array}{l}\text { Azar S.A. Measuring the US social } \\
\text { discount rate. Applied Financial } \\
\text { Economics Letters, 2007, 3, 63-66. }\end{array}$ & Market & $5,0-6,0$ \\
\hline & 2008 & Office of Management and Budget & SOC & $2,5-3,0$ \\
\hline & 2009 & $\begin{array}{l}\text { Azar S.A. A Social Discount Rate } \\
\text { for the US. International Research // } \\
\text { Journal of Finance and Economics. } \\
\text { Issue 25, } 2009 .\end{array}$ & SRTP & 3,7 \\
\hline \multirow[b]{2}{*}{ South Africa } & 2002 & Water project research commission & $\begin{array}{l}\text { SRTP } \\
\text { SOC }\end{array}$ & 8,0 \\
\hline & 2004 & $\begin{array}{l}\text { Mario du Preez. The Discount Rate for } \\
\text { Public Sector Conservation Projects in } \\
\text { South Africa. African Development Bank } \\
\text { 2004. Published by Blackwell Publishing }\end{array}$ & SRTP & $2,5-5,0$ \\
\hline
\end{tabular}




\begin{tabular}{|c|c|c|c|c|}
\hline \multicolumn{5}{|c|}{ Continuation of Table 1} \\
\hline Country & Year & Author & $\begin{array}{l}\text { Calculation } \\
\text { approach }\end{array}$ & $\begin{array}{c}\text { Value, } \\
\%\end{array}$ \\
\hline India & 2004 & $\begin{array}{l}\text { Kula E. Estimation of a Social Rate } \\
\text { of Interest for India // Journal of } \\
\text { Agricultural Economics Volume 55, } \\
\text { No. } 12004, \text { pp. 91-99. }\end{array}$ & SRTP & 5,2 \\
\hline Brazil & 2008 & \multirow{9}{*}{$\begin{array}{l}\text { Lopez H. The Social Discount Rate: } \\
\text { Estimates for nine Latin American } \\
\text { countries. The World Bank, Policy } \\
\text { Research Working Paper 4639, } 2008 .\end{array}$} & SRTP & 5,1 \\
\hline Chile & 2008 & & SRTP & 4,6 \\
\hline Colombia & 2008 & & SRTP & 4,2 \\
\hline Mexico & 2008 & & SRTP & 3,3 \\
\hline Peru & 2008 & & SRTP & 3,1 \\
\hline Argentina & 2008 & & SRTP & 2,9 \\
\hline Honduras & 2008 & & SRTP & 2,1 \\
\hline Bolivia & 2008 & & SRTP & 1,9 \\
\hline Nicaragua & 2008 & & SRTP & 0,9 \\
\hline Russia & 2010 & $\begin{array}{c}\text { Sheluntsova M.А. Особенности } \\
\text { оценки социальной ставки дискон- } \\
\text { тирования для развивающихся стран } \\
\text { [Рecularities of social discount rate } \\
\text { estimation in developing countries] / } \\
\text { M.A. Sheluntsova // Finance and } \\
\text { credit. - № 27(411) - 2010. - Pp. 57-64. }\end{array}$ & SRTP & $\begin{array}{l}2,8- \\
10,0\end{array}$ \\
\hline \multirow{3}{*}{ Great Britain } & 1995 & $\begin{array}{c}\text { Pearce D.W., Ulph. D. A Social } \\
\text { Discount Rate for the United } \\
\text { Kingdom. CSERGE Working Paper } \\
\text { 95-01. Centre for Social and Economic } \\
\text { Research on the Global Environment, } \\
\text { University of East Anglia, UK. - 1995. }\end{array}$ & SRTP & $2,0-4,0$ \\
\hline & 2003 & $\begin{array}{c}\text { The Grren Book: Appraisal and } \\
\text { Evaluation in Central Government, } \\
\text { Treasury Guidence. London: } \\
\text { TSO 2011. } 114 \text { p. Retrieved from: } \\
\text { https://www.gov.uk/ } \\
\text { government/uploads/ } \\
\text { system/uploads/attachment_data/ } \\
\text { file/220541/ } \\
\text { green_book_complete.pdf }\end{array}$ & $\begin{array}{l}\text { SRTP } \\
\text { SOC }\end{array}$ & 3,5 \\
\hline & 2004 & $\begin{array}{l}\text { Evans D. J. and Sezer H. Social } \\
\text { discount rates for six major countries. } \\
\text { Applied Economics Letters, 11, } \\
\text { 2004. - Pp. 557-560. }\end{array}$ & SRTP & 4,2 \\
\hline
\end{tabular}


End of Table 1

\begin{tabular}{|c|c|c|c|c|}
\hline Country & Year & Author & $\begin{array}{c}\text { Calculation } \\
\text { approach }\end{array}$ & $\begin{array}{c}\text { Value, } \\
\%\end{array}$ \\
\hline Great Britain & 2005 & $\begin{array}{l}\text { Evans D., Sezer H. Social discount } \\
\text { rates for member countries of the } \\
\text { European Union. Journal of Economic } \\
\text { Studies, Vol. 32, No.1, 2005, pp. 47-59. }\end{array}$ & SRTP & 4,0 \\
\hline \multirow[t]{2}{*}{ Italy } & 2005 & $\begin{array}{c}\text { Evans D. J. and Sezer H. Social } \\
\text { discount rates for six major countries. } \\
\text { Applied Economics Letters, 11, } \\
\text { 2004. - Pp. 557-560. }\end{array}$ & SRTP & 4,7 \\
\hline & 2008 & $\begin{array}{l}\text { Percoco M. A social discount rate } \\
\text { for Italy. Applied Economics Letters, } \\
2008,15,73-77 \text {. }\end{array}$ & SRTP & $3,7-3,8$ \\
\hline \multirow{3}{*}{ France } & 2001 & OECD & $\begin{array}{l}\text { Marginal } \\
\text { product of } \\
\text { Capital }\end{array}$ & 8,0 \\
\hline & 2004 & $\begin{array}{l}\text { Evans D. J. and Sezer H. Social } \\
\text { discount rates for six major countries. } \\
\text { Applied Economics Letters, 11, } \\
\text { 2004. - Pp. 557-560. }\end{array}$ & SRTP & 3,5 \\
\hline & 2005 & $\begin{array}{l}\text { Evans D., Sezer H. Social discount } \\
\text { rates for member countries of the } \\
\text { European Union. Journal of Economic } \\
\text { Studies, Vol. 32, No.1, 2005, pp. 47-59. }\end{array}$ & SRTP & 3,2 \\
\hline
\end{tabular}

Source: $[1 ; 32 ; 33 ; 34 ; 35]$

Development and Trade of Ukraine (Letter No. 4001-08 / 6049-03 as of 15.02.2018): "future cash flows should be discounted in accordance with real discount rates, namely: social discount rate for projects implemented in these areas, where the state fully provides services and the business market is completely absent, is $5 \%$; discount rate for projects implemented in these areas, where the market is present and business is developing, is $12 \%$ ». The basic approach for such values is not identified.

As it has been mentioned before, the SDR indicator is used to evaluate and select the best investment projects in accordance with the major point of view across society. Thus, an appropriate SDR calculation is an important practical task in Ukraine.

The authors propose to use a modified Ramsay formula to calculate the SDR in accordance with the "social rate of time preferences" approach. 
The modified formula was obtained by solving the problem of maximizing the utility function under the following assumptions:

1) the values of $\rho$ and $\mu$ parameters are variable (the values are not constant);

2) the function with constant elasticity of marginal utility (2) at time point $t$ should show a downward trend in consumption growth in accordance with utilitarian approach [28];

3 ) the research was considered based on the approach to the solution of the equation (2), proposed by V. Khayrullin and E. Shakirova [36, p. 197]. The formula of calculation got the following form:

$$
\begin{gathered}
S T P R=-\frac{\frac{d}{d t}\left(\frac{d\left(U\left(C_{t}\right) e^{-\beta t}\right)}{d C_{t}}\right)}{\frac{d\left(U\left(C_{t}\right) e^{-\beta t}\right)}{d C_{t}}}=-\frac{\frac{d}{d t}\left(C_{t}^{-\mu} e^{-\phi p t}\right)}{C_{t}^{-\mu} e^{-\rho t}}=\rho_{t}+t \frac{d \rho_{t}}{d t}+\mu_{t} \frac{1}{C_{t}} \frac{d C_{t}}{d t}+\ln \left(C_{t}\right) \frac{d \mu_{t}}{d t} \Rightarrow \\
S T P R=\rho_{t}+t \Delta \rho_{t}+\mu_{t} g+\ln \left(C_{t}\right) \Delta \mu_{t}
\end{gathered}
$$

4) considering the monthly differentiation of per capita consumer spending (in UAH) within crisis and economic growth periods, $\ln \left(C_{t}\right)$ was proposed to be used as an average square of these expenditures in the inter-crisis timeframe;

5) considering the rule for investment projects to be of a long-term nature, the lifetime risk indicator was supplemented by the average rate of such risk increase, determined over the same timeframe as in the previous clause.

Thus, the formula social discount rate calculation looks in the following way:

$$
S T P R=\left(\rho_{t}+\delta_{t}\right)+\overline{\Delta \rho_{t}}+\mu_{t} g+\sigma\left(C_{t}\right) \Delta \mu_{t},
$$

where $S T P R$ - social discount rate, $\rho_{t}-$ life risk level, $\mu_{t}-$ the marginal utility elasticity that is defined by the formula (4), $g$ - consumption derivative ratio, $C_{t}-$ monthly per capita consumer spending, UAH.

The parameter $\rho_{t}$ is considered in case of its division into two components, namely: $\delta$ is the «net» rate of of time preferences and $\rho$ means the level of life risk. Nevertheless, $\delta$ is equal to $0,44 \%$ and $\rho$ is considered as the ratio of the number of people who did not survive before the end of the project to the total population, based on the deaths quantity per thousand people. It is appropriate to use the per capita consumption growth rate for parameter $g$ determination. 
As the result of all previously made necessary assumptions and all necessary data summarize, the social discount rate was calculated for the timeframe of 2008-2018. The obtained SDR indicators are presented in Table 2.

Table 2

Social discount rate in Ukraine, \%

\begin{tabular}{|l|l|l|l|l|l|l|l|l|l|l|l|}
\hline \multicolumn{1}{|c|}{ Timeframe } & $\mathbf{2 0 0 8}$ & $\mathbf{2 0 0 9}$ & $\mathbf{2 0 1 0}$ & $\mathbf{2 0 1 1}$ & $\mathbf{2 0 1 2}$ & $\mathbf{2 0 1 3}$ & $\mathbf{2 0 1 4}$ & $\mathbf{2 0 1 5}$ & $\mathbf{2 0 1 6}$ & $\mathbf{2 0 1 7}$ & $\mathbf{2 0 1 8}$ \\
\hline $\begin{array}{l}\text { International } \\
\text { experience } \\
\text { (Ramsey } \\
\text { methodology) }\end{array}$ & 15,51 & 16,58 & 12,05 & 9,43 & 5,83 & 8,23 & 12,90 & 15,14 & 10,15 & 8,56 & 8,10 \\
\hline $\begin{array}{l}\text { M. Sheluntsova } \\
\text { approach }\end{array}$ & 14,71 & 17,37 & 12,09 & 9,42 & 5,89 & 8,38 & 13,31 & 14,99 & 10,05 & 8,25 & 7,98 \\
\hline $\begin{array}{l}\text { Authorial } \\
\text { approach } \\
\text { (formula 14) }\end{array}$ & 9,73 & 20,17 & 10,06 & 9,62 & 6,65 & 9,50 & 13,94 & 13,71 & 10,36 & 8,44 & 8,81 \\
\hline
\end{tabular}

In accordance with the results of the calculations presented in Table 2 it is possible to observe a significant increase in the social discount rate value in the crisis years of 2009 and 2014-2015. This is caused by the elasticity of marginal utility of consumption increase as in case of the population incomes grow with a tendency to save and increase in consumption. Then, the social discount rate value is low during the period 2010-2013 and 2016-2018 that means a decrease in requirements for social projects within society.

The SDR calculation in Ukraine are provided based on the "social opportunity cost of capital" approach in accordance with A. Boardman algorithm [27]. The following parameters have been defined:

- risk-free interest rate $\left(r_{f}\right)$ - average level of domestic public debt profitability (the equivalent to the average annual profitability of long-term corporate bonds with high credit rating in USA) - 17,97\%;

- income tax $(\operatorname{tax})-18 \%$;

- nominal rate before tax: $r_{n}=\left[r_{f} /(1-\operatorname{tax})\right]=[0,1797 /(1-0,18)]=0,2191$;

- an average annual inflation rate $\left(T_{i}\right)-9,8 \%$;

- respectively: $S O C=\left[\left(r_{n}-T_{i}\right) /\left(1+T_{i}\right)\right]=[(0,2191-0,098) /(1+0,098)]=$ $=0,1103(11,03 \%)$.

The obtained SDR values comparison enables to confirm validity of the authorial method and its practical significance. The attention should be paid 
to the fact that the proposed approach to the SDR calculation has another qualitative advantage. In particular, the obtained indicator is very sensitive to the crisis manifestations within the economy that can be seen in Table 2 .

\section{Conclusions}

The paper provides the theoretical summarize of the methodological approaches to SDR definition. These findings contribute to solution of scientific task of SDR calculation at the national level in Ukraine is provided. In conclusion, this study shows the following aspects:

1. The theoretical research of SDR and practical experience of its calculation in different countries has shown the importance of this indicator within the financial calculations and feasibility studies of investment projects preparation, in particular it is important in public sector. At the same time, there are no Ukrainian studies on the SDR definition and use. As the result, the last one is not used in an appropriate way in case of investment projects implementation. This reduces the results reliability. Thus, entities, conducting economic calculations, take into account the discount rate set by the Ukrainian Government in the amount of $5 \%$ or $12 \%$. However, there is almost no review of such discount rate. Neither economic increase nor decrease are taking into account.

2. The present study has demonstrated that there are four main approaches to define SDR within the market economy, namely: 1) an approach based on the concept of social rate of time preferences (SRTP); 2) social opportunity cost of capital (SOC) approach; 3) approach is based on shadow price of capital (SPC) concept; 4) a consumer equivalence approach $\left(\mathrm{SDR}_{\mathrm{CEM}}\right)$. Despite numerous studies, economists did not agree on the choice of the most appropriate approach for SDR calculation. The difference approaches are largely reflecting a great measure of views on the way public investment affects the national economy, displacing the private investment or reinvesting. Despite the fact that SRTP is the main method of SDR calculation, the SOC method is equally important in terms of valuation, because it allows determining correctly the value of the social rate in case the social problem is solved not only by the state but also by the private investor.

3. Analysis of SDR research, conducted by scientists worldwide, shows that SDR calculation is often based on long-term retrospective data. For instant, the retrospective data of SRTP during the last 60 years and SOC 
data during 50 years were used within SDR determination research in the USA. In accordance with practical experience, the SRTP approach is more commonly used in developed countries. At the same time, the SOC method is rather popular in developing ones. In addition, it has been found that the SDR value is rather variable in developed and developing countries. This fact is explained by the higher value of current consumption (marginal utility) for developing countries.

4. The lack of statistical information creates limits for SDR models use and forces the adaptation of existing international approaches to Ukrainian realities. For instance, like the proposed formula number 14 . The authorial approach to SDR calculation for development countries takes into account the following aspects: a) life risk level fluctuations and the elasticity of marginal social utility of consumption; b) differentiation of monthly consumer spending per capita (in UAH) in crisis periods and periods of economic growth; c) supplementing the risk to life indicator with the average rate of such risk increase; d) the methodology for determining the net rate of time preferences, when public investment determines postponed consumption; e) the expected growth rate of per capita consumption and the elasticity of marginal utility of consumption. As a result, the proposed approach allows an adequate assessment of the public ability to perceive public spending.

5. The social discount rate calculation by different methods for Ukrainian economy in 2018 provides the following values: SOC - 11,03\%; SRTP (Ramsay method) - 8,10\%; SRTP (modified Sheluntsova method) $7,98 \%$; SRTP (authorial approach) - 8,81\%. Therefore, the necessary capital volume to finance public investment projects or private investor projects involving public resources fully satisfies consumers in Ukraine, because the SRTP value is lower than SOC. The authors approach to SDR calculations, that are represented in Table 2, has proved its advantages, concerning the sensitivity of the obtained indicator to the of crisis phenomena manifestations in the economy.

\section{References:}

1. Zhuang, J., Hang, Z., Lin, T., \& De Guzman, F. (2007). Theory and practice in the choice of social discount rate for cost-benefit analysis: a survey. ERD Working Paper, No. 94. Asian Development Bank.

2. Ramsey, F. (1928). A mathematical theory of saving. Economic Journal 38, pp. 543-559. 
3. Baumol W. (1968). On the Social of Discount, American Economic Review. Vol. 58. September, pp. 788-802.

4. Marglin S.A. (1963). The Opportunity Cost of Public Investment. Quaterly Journal of Economics. Vol. 77.

5. Azar S.A. (2009). Social Discount Rate for the US. International Research Journal of Finance and Economics.

6. Percoco M.A. (2008). Social discount rate for Italy. Applied Economics Letters, 15 , pp. 73-77.

7. Lopez H. (2008). The Social Discount Rate: Estimates for nine Latin American countries. The World Bank, Policy Research Working Paper 4639.

8. Moore, M.A., Boardman, A.E., \& Vining, A.R. (2013). More appropriate discounting: the rate of Social time preference and the value of social discount rate. Journal of Benefit-Cost Analysis. 4, 1-16.

9. Burgess, D.F., \& Zerbe, R.O. (2013). The most appropriate discount rate. Journal of Benefit-Cost Analysis, 4, pp. 391-400.

10. Park, S. (2012). Optimal discount rates for government projects. ISRN Economics. doi:10.5402/2012/982093

11. Halicioglu, F., \& Karatas, C. (2011). A social discount rate for Turkey. Quality \& Quantity, 47, pp. 1085-1091.

12. Scarborough, H. (2011). Intergenerational equity and the social discount rate. The Australian Journal of Agricultural and Resource Economics, 55, pp. 145-158.

13. Shelunstsova, M. (2009). Evaluation of a social discount rate for the Russian federation, the International Conference on Administration and Business. Bucharest, Romania, pp. 714-720.

14. Evans, D.J., \& Sezer, H. (2005). Social discount rates for member countries of the European Union. Journal of Economic Studies, 32, pp. 47-59.

15. Spackman, M. (2004). Time discounting and of the cost of capital in government. Fiscal Studies, 25, pp. 467-518.

16. Kula, E. (2004). Estimation of a social rate of interest for India. Journal of Agricultural Economics, 55, pp. 91-99.

17. Harrison, M. (2010). Valuing the future: the social discount rate in cost-benefit analysis. Visiting Research Paper, Australian Government Productivity Commission, Canberra.

18. Hepburn, C. (2006). Use of discount rates in the estimation of the costs of inaction with respect to selected environmental concerns. Working Party on National Environmental Policies. Final Report, OECD, 42.

19. Vasjutynsjka L.A. (2014). Ocinka socialjnoji stavky dyskontuvannja: metodychni pidkhody [Social Discount Rate Estimation: methodological approaches] University Economic Bulletin: Collection of Scientific Papers. Pereyaslav-Khmelnitsky, pp. 180-186.

20. Livshits V.N. (1984). Optimizatsiya pri perspektivnom planirovanii i proektirovanii. [Optimization with long-term planning and design] Moscow: Ekonomik. (in Russian)

21. Fedorenko N.P., \& L’vov D.S. (1989). Kompleksnaya otsenka effektivnosti meropriyatiy, napravlennykh na uskorenie nauchno-tekhnicheskogo progressa. Metodicheskie rekomendatsii [A comprehensive assessment of the effectiveness of 
measures aimed at accelerating scientific and technological progress. Guidelines]. Moscow: Informelektro. (in Russian)

22. Pearce D., \& Ulph. D (1995). A Social Discount Rate for the United Kingdom. CSERGE Working Paper 95-01. Centre for Social and Economic Research on the Global Environment, University of East Anglia, UK (electronic journal). Retrieved from: http://citeseerx.ist.psu.edu/viewdoc/download?doi $=10.1 .1 .458 .9912 \&$ rep=rep1\&type $=$ pdf (accessed 19.09.2019).

23. Stern N.H. (1977). Welfare Weights and the Elasticity of the Marginal Valuation of Income // M.J. Artis, A.R. Norbay (eds.). Studies in Modem Economic Analysis: Proceedings of the Annual Conference of the Association of University Teachers of Economics. Blackwell, Oxford, pp. 209-257.

24. Derzhavna sluzhba statystyky Ukrainy (2019). Kyiv: Informatsiino-analitychne ahentstvo. Retrieved from: http://www.ukrstat.gov.ua/ (accessed 20.10.2019).

25. Pearce D., \& Ulph D. (1999). A social discount rate for the UK// D. W. Pearce (ed.) Economics and the Environment: Essays on Ecological Economics and Sustainable Development, Edward Elgar, Cheltenham, pp. 268- 285.

26. Arkhipov V.M., \& Emel'yanov A.M. (2006). Otsenka sotsial'noy stavki diskontirovaniya [Assessment of the social discount rate] Finance and Credit, no. 17, pp. 10-15.

27. Boardman A., Greenberg D., Vining A., \& Weimer D. (2001). Cost-Benefit Analysis: Concepts and Practice, 2nd ed. Upper Saddle River, NJ: Prentice-Hall.

28. Lyon, R. (1990). Federal Discount Rate Policy, the Shadow Price of Capital, and Challenges for Reforms. Journal of Environmental Economics and Management 18: s. 29-50.

29. Zerbe, Jr.R., \& Dively, D. (1994). Benefit-Cost Analysis: In Theory and Practice. New York: Harper Collins.

30. Musgrave R.A., \& Musgrave P.B. (1989). Public finance in theory and practice. New York: McGraw-Hill.

31. Harberger, A., \& Jenkins G. (2002). Cost-Benefit Analysis for Investment Decisions. Queen's University, Canada.

32. Sheluntsova M.A. (2010). Voprosy ekonomicheskoy teorii. Makroekonomika [Questions of economic theory. Macroeconomics]. Eurasian international scientific and analytical journal Problems of the modern economy, no. 4(36).

33. Salvador Cruz Rambaud, María José Muñoz Torrecillas (2006). Social Discount Rate: A Revision. Anales de Estudios Económicos y Empresariales, Vol. XVI, pp. 75-98.

34. Massimo Florio and Emanuela Sirtori The social cost of capital: RECENT ESTIMATES FOR THE EU COUNTRIES. Working Paper N. 03/2013.

35. Kazlauskiena Vilma (2015). Application of social discount rate for assessment of public investment projects. Social and Behavioral Sciences (electronic journal), vol. 213, pp. 461-467. Retrieved from: https://www.sciencedirect.com/ science/article/pii/S1877042815057894 (accessed 20.09.2019).

36. Khayrullin V.A., \& Shakirova E.V. (2012). Sotsial'naya norma diskonta pri osvoenii investitsiy $\mathrm{v}$ sotsial'nye proekty toplivno-energeticheskogo kompleksa respubliki Bashkortostan [Social rate of discount when developing investments in social projects of the fuel and energy complex of the Republic of Bashkortostan]. Oil and gas business, vol. 10, no. 3 . 